\title{
FIRMNESS AND ANTIOXIDANT CAPACITY \\ OF HIGHBUSH BLUEBERRY (VACCINIUM CORYMBOSUM L.) GROWN ON THREE TYPES OF ORGANIC BED
}

\author{
Józef GRAJKOWSKI ${ }^{1}$, Ireneusz OCHMAN ${ }^{1}$, Zbigniew MULIŃSKI $^{2}$ \\ ${ }^{1}$ Pomology Department \\ ${ }^{2}$ Department of General Chemistry \\ Agricultural University \\ Słowackiego 17, 71-434 Szczecin
}

\begin{abstract}
Summary
An experiment was carried out in 2004-2005 to study the influence of bed and storage on fruit quality of highbush blueberry 'Patriot'. The bushes were grown on three different types of organic bed irrigated with acidified water $(\mathrm{pH}$ 2.4-3.7). Measurements were made of firmness, size and antioxidant capacity $\left(\mathrm{nmol}\right.$ Trolox $\left.\cdot \mathrm{g}^{-1}\right)$. The measurements were carried out at harvest and then at one and two weeks of cold storage. Firmness measurements were taken on the fruit equatorial (diameter) axis. Fruit from bushes growing on peat had the highest firmness values while fruit from bushes growing on Cocoa husk had the lowest. Comparisons were made of firmness using either the equatorial or polar (stemcalyx) axis of the blueberry. It was found that the polar axis measurements were over two times higher than the equatorial axis. Storing highbush blueberries in a cold room is essential in maintaining firmness. The average fruit size of ' $\mathrm{Pa}$ triot' was between $11.2 \mathrm{~mm}$ and $13.4 \mathrm{~mm}$ in height and $17.7 \mathrm{~mm}$ to $21.1 \mathrm{~mm}$ in diameter.

Fruit harvested from bushes planted on peat had the highest antioxidant capacity with the lowest coming from bushes planted on Cocoa husk (nmol Trolox $\left.\cdot \mathrm{g}^{-1}\right)$. There was no significant difference in antioxidant activity from harvest to the end of the storage period.
\end{abstract}

key words: antioxidant capacity, firmness, peat, cocoa husk, sawdust, total yield, growth

\section{INTRODUCTION}

Highbush blueberry (Vaccinium corymbosum L.) is one of the most recent domesticated fruit species. It is an excellent example of how a wild plant, coming from forest vegetation, becomes a useful farm plant. It was mainly cultivated in North America and recently European countries have taken an interest in it (Kader et al. 1996). The blueberry fruit is found to be one of the healthiest

Corresponding author:

e-mail:sad@agro.ar.szczecin.pl,ochmian@go.2.pl

(C) Copyright by RIVC 
grocery items due to its dietary value and antioxidant activity (Mainland et al. 2002, Ścibisz \& Mitek 2002). The antioxidant capacity is not a constant characteristic but rather depends on the cultivar, growing conditions (Prior et al. 1998) and storage conditions (Horubała 1999). Maintenance of high food quality during storage as well as being aestheticly pleasing after storage is very important.

The purpose of this experiment was to evaluate firmness and antioxidant capacity of 'Patriot' highbush blueberry at harvest and during cold storage.

\section{MATERIALS AND METHODS}

The experiment was carried out in 2004-2005 at the Experimental Fruitgrowing Station of the Szczecin University of Agriculture. Embankments $35 \mathrm{~cm}$ high and $100 \mathrm{~cm}$ wide were made.

The three types of bed used to make the embankments were:

1. acid reaction mursh soil (peat)

2. composted cocoa husk (waste of chocolate production)

3. composted coniferous sawdust.

'Patriot' bushes were planted in 2002 (spacing of $1.5 \times 2.5 \mathrm{~m}$ ) in each prepared embankment. The plantation was irrigated each year by means of a TTape type fixed drip system and the water applied was acidified. The irrigation rate changed depending upon the soil moisture content as measured by contact soil tensiometers.

Table 1. Chemical-physical properties of tap water used through the experiment

\begin{tabular}{cccc}
\hline \multicolumn{2}{c}{$\begin{array}{c}\text { Acidified water to irrigate husk } \\
\text { and sawdust }\end{array}$} & \multicolumn{2}{c}{ Acidified water to irrigate peat } \\
\hline $\begin{array}{c}\mathrm{EC} \\
\left(\mathrm{mS} \cdot \mathrm{cm}^{-2}\right)\end{array}$ & $\mathrm{pH}$ & $\begin{array}{c}\mathrm{EC} \\
\left(\mathrm{mS} \cdot \mathrm{cm}^{-2}\right)\end{array}$ & $\mathrm{pH}$ \\
\hline 2.46 & 2.36 & 2.01 & 3.72 \\
\hline
\end{tabular}

Check tests were made on representative fruit samples harvested from test bushes for antioxidant capacity (method by Miller and Rice-Evans), firmness and size (measured by non-destructive FirmTech- 2 instrument) at harvest and after one and two weeks of cold storage (temperature $2^{\circ} \mathrm{C}$ and humidity $96 \%$ ). The firmness and size measurements were carried out on 120 fruit (20 fruit from the same bush).

The experiment was a random sub-block design with 6 replicates The analysis of variance was used every year to identify the significance of the influence of the beds on the growth and the synthesis to cover all the experiment years followed. The average values were verified by means of the Duncan's multiple range test and the NIR was calculated for $\mathrm{P}=0.05$. 


\section{RESULTS AND DISCUSSION}

Based on a two-year observation, the antioxidant capacity of 'Patriot' depended upon the organic bed in which it was grown (Table 2). The bushes planted on peat had the best antioxidant capacity $\left(42.2 \mathrm{nmol} \mathrm{Trolox} \cdot \mathrm{g}^{-1}\right.$ of fruit), while that of cocoa husk and sawdust was lower. 'Patriot' highbush blueberry was similar to 'Bluecrop', but surpassed 'Jersey' and 'Lateblue' as described by Ścibisz et al. (2003) in antioxidant capacity. It was found that fruit stored for two weeks did not have reduced antioxidant capacity. Ścibisz \& Mitek (2001) stated that freezing also does not significantly influence the fruit' antioxidant capacity.

Table 2. Antioxidant capacity of highbush blueberries (nmol Trolox $\left.\cdot \mathrm{g}^{-1}\right)$. Analysis for 2004-2005

\begin{tabular}{lcccc}
\hline Organic bed & at harvest & 1 week of storage & 2 weeks of storage & Mean \\
\hline Peat & $42.2 \mathrm{~b}$ & $42.4 \mathrm{~b}$ & $39.8 \mathrm{~b}$ & $41.5 \mathrm{~b}$ \\
Cocoa husk & $32.3 \mathrm{a}$ & $31.2 \mathrm{a}$ & $30.4 \mathrm{a}$ & $31.3 \mathrm{a}$ \\
Sawdust & $33.3 \mathrm{a}$ & $30.1 \mathrm{a}$ & $30.7 \mathrm{a}$ & $31.4 \mathrm{a}$ \\
Mean & $35.9 \mathrm{a}$ & $34.6 \mathrm{a}$ & $33.6 \mathrm{a}$ & \\
\hline
\end{tabular}

Note: Means followed by the same letter do not differ significantly at $\mathrm{P}=0.05$ according to Duncan's multiple range test

Firmness was determined using both the equatorial axis and the polar axis (Table 3). The same fruit was used for both tests. Using the equatorial axis position, there was no significant difference in harvested fruit between the peat and sawdust beds. The fruit from the cocoa husk bed was significantly lower at harvest and continued to be significantly lower during storage. There was a significant decrease in firmness from all the fruit during storage compared with harvest however the peat and sawdust beds were higher than the cocoa husk beds.

Table 3. Firmness of the blueberry fruit. Analysis for 2004-2005

\begin{tabular}{|c|c|c|c|c|}
\hline \multirow[t]{2}{*}{ Organic bed } & \multicolumn{4}{|c|}{$\begin{array}{l}\text { Fruit firmness measured along the equatorial axis } \\
\qquad\left(\mathrm{G} \cdot \mathrm{mm}^{-1} \text { deflection }\right)\end{array}$} \\
\hline & at harvest & 1 week of storage & 2 weeks of storage & Mean \\
\hline Peat & $206 \mathrm{e}$ & $198 \mathrm{de}$ & $185 \mathrm{~b}$ & $196 b$ \\
\hline Cocoa husk & $182 \mathrm{bc}$ & $176 \mathrm{~b}$ & $160 \mathrm{a}$ & $173 a$ \\
\hline Sawdust & $196 \mathrm{de}$ & $190 \mathrm{~cd}$ & $179 \mathrm{~b}$ & $188 b$ \\
\hline \multirow[t]{2}{*}{ Mean } & $195 \mathrm{a}$ & $188 \mathrm{a}$ & $175 b$ & \\
\hline & \multicolumn{4}{|c|}{$\begin{array}{l}\text { Fruit firmness measured along the polar axis } \\
\qquad\left(\mathrm{G} \cdot \mathrm{mm}^{-1} \text { deflection }\right)\end{array}$} \\
\hline Organic bed & at harvest & 1 week of storage & 2 weeks of storage & Mean \\
\hline Peat & $492 \mathrm{e}$ & $490 \mathrm{e}$ & $478 \mathrm{de}$ & $487 \mathrm{c}$ \\
\hline Cocoa husk & $440 \mathrm{ab}$ & $435 \mathrm{a}$ & $429 a$ & $435 \mathrm{a}$ \\
\hline Sawdust & $472 \mathrm{~d}$ & $462 \mathrm{~cd}$ & $456 \mathrm{bc}$ & $461 \mathrm{~b}$ \\
\hline Mean & $468 \mathrm{a}$ & $462 \mathrm{a}$ & $452 \mathrm{a}$ & \\
\hline
\end{tabular}

Note: see Table 2 
The firmness of the blueberry fruit along the polar axis was double compared with the values along the equatorial axis. The bushes growing on peat had significantly firmer fruit at harvest than the fruit from the other beds.

It was observed that the fruit firmness, when measured on the polar axis, was not significantly reduced during storage (from $2.5 \%$ on peat to $3.4 \%$ on sawdust). There was a significant difference in firmness using the equatorial axis method (from $8.7 \%$ on sawdust to $12.1 \%$ on cocoa husk), however.

An important characteristic for production is fruit size. The average fruit size of 'Patriot' measured in the 2004-2005 season is shown in Table 4. There was a significant difference with height and width between blueberries grown in the peat and cocoa husk beds but not in the sawdust bed. Fruit of this study were larger compared with a four cultivar trial by Ścibisz et al. (2003).

Table 4. Size of the blueberry fruit. Analysis for 2004-2005

\begin{tabular}{lccc}
\hline & Peat & Cocoa husk & Sawdust \\
\hline Fruit size - equatorial axis $(\mathrm{mm})$ & $21.1 \mathrm{~b}$ & $17.7 \mathrm{a}$ & $19.6 \mathrm{ab}$ \\
Fruit size - polar axis $(\mathrm{mm})$ & $13.4 \mathrm{~b}$ & $11.2 \mathrm{a}$ & $12.4 \mathrm{ab}$ \\
\hline
\end{tabular}

Note: see Table 2

\section{CONCLUSIONS}

1. Fruit harvested from bushes planted on peat showed the highest antioxidant capacity, firmness and size while that of cocoa husk showed the least.

2. The firmness of the highbush blueberry fruit along the polar axis was double compared with the values along the equatorial axis.

3. It was found that fruit stored for up to two weeks did not lose its antioxidant capacity.

4. The reduction of blueberry fruit firmness after two weeks storage measured along equatoral axis was about $10 \%$.

\section{REFERENCES}

Horubała A. 1999. Pojemność przeciwutleniająca i jej zmiany w procesach przetwarzania owoców i warzyw. Przem. Ferm. i Owoc.-Warz. 3: 30-32. [in Polish]

Kader R., Rovel B., Girardin M., Metche M. 1996. Fractionation and identification of the phenolic compounds of Highbush blueberries (Vaccinium corymbosum). Food Chem. 55 (1): 35-40.

Mainland C.M., Tucker J.W., Hepp R.F. 2002. Blueberry health information - some new mostly review. Acta Hort. 574: 39-43.

Prior R.L. Cao G., Martin A., Sofic E., McEwen J., O’Brien C., Liscshner N., Ehlenfeldt M., Kalt W., Krewer G., Mainland C.M. 1998. Antioxidant capacity as influenced by total phenolic and anthocyanin content, maturity and variety Vaccinium species. J. Agric. Food Chem. 46: 2686-2693. 
Ścibisz I., Mitek M. 2001. Pojemność przeciwutleniająca borówki wysokiej i jej zmiany podczas przetwarzania i przechowywania. Zesz. Nauk. Inst. Sadow. i Kwiac. Skierniewice. 9: 283-288. [in Polish]

Ścibisz I., Mitek M. 2002. Właściwości zdrowotne i możliwości przetwórcze borówki wysokiej. Sad Now. 1: 24-25. [in Polish]

Ścibisz I., Mitek M., Malewska J. 2003. Aktywność przeciwutleniająca owoców borówki wysokiej. Żywność. 2(35) suplement: 159-166. [in Polish]

\title{
JĘDRNOŚĆ ORAZ POJEMNOŚĆ PRZECIWUTLENIAJACCA OWOCÓW BORÓWKI \\ AMERYKAŃSKIEJ (VACCINIUM CORYMBOSUM L.) PO OKRESIE PRZECHOWYWANIA UPRAWIANEJ W TRZECH TYPACH PODŁOŻY ORGANICZNYCH
}

\begin{abstract}
Streszczenie
Doświadczenie, którego celem było zbadanie wpływu podłoży oraz przechowywania na jakość owoców borówki wysokiej odm. Patriot, przeprowadzono w latach 2004-2005. Krzewy posadzono w trzech typach podłoży organicznych nawadnianych zakwaszaną wodą (pH 2.4-3.7) za pomocą linii kroplującej. Przyrządem komputerowym FirmTech każdorazowo na tych samych owocach mierzono jędrność i automatycznie wielkość owoców oraz pojemność przeciwutleniającą (nmol Troloxu $\cdot \mathrm{g}^{-1}$ ). Pomiary przeprowadzano bezpośrednio po zbiorze oraz po 1 i 2 tygodniach przechowywania w chłodni zwykłej.

Badaniom wytrzymałości na ściskanie poddano owoce zarówno w osi ich średnicy jak i w osi ich wysokości. Najwyższą jędrność mierzoną w osi średnicy stwierdzono u owoców z krzewów rosnących na torfie, natomiast najniższą - z krzewów na łusce kakaowej. Jędrność owoców borówki mierzona w osi wysokości była ponad 2-krotnie wyższa w porównaniu z osią średnicy. Przechowywanie owoców wpłynęło istotnie na obniżenie jędrności owoców. Średnia wielkość owoców odm. Patriot zawierała się w granicach od 8,5 mm wysokości i 16,6 mm średnicy dla borówki rosnącej na łusce kakaowej do $10,5 \mathrm{~mm}$ wysokości i $18,7 \mathrm{~mm}$ średnicy dla borówki rosnącej na torfie.

W 2004 roku owoce zebrane z krzewów posadzonych w torfie charakteryzowały się największą pojemnością przeciwutleniająca, natomiast zdecydowanie najmniejszą owoce z łuski kakaowej. Natomiast w 2005 roku owoce zebrane z podłoża torfowego miały istotnie najmniejszą pojemność przeciwutleniającą mierzoną ymol Troloxu. W czasie trwania doświadczenia nie zaobserwowano znaczącego wpływu długości przechowywania na dany parametr.
\end{abstract}

